\title{
PERAN PEREKAM MEDIS DALAM MENJAGA KERAHASIAAN DATA GENETIC SCREENING PASIEN
}

\author{
${ }^{1}$ Tiffany Carina Oriordan, ${ }^{2}$ Savitri Citra Budi \\ D3 Rekam Medis Universitas Gadjah Mada ${ }^{1,2}$, \\ tiffanycarina@hotmail.com ${ }^{1}$, vi3ku@yahoo.com²
}

\begin{abstract}
The purpose of this study was to determine the role of the medical record in the application of genetic screening methods. This research is a descriptive qualitative study approach document. Documents in the form of several international journals which includes the case of genetic screening as well as other books that relevan. Genetic Screening or generally called DNA testing is a method to determine abnormalities that occur in DNA. The results of genetic screening can be used as a reference a disease preventive measures. However, the adverse effects of genetic screening is adverse discrimination not only for the individual but also the surrounding environment. This discrimination can be minimized by the implementation of good management of medical records and completely covers the filling informed consent, multiple database creation, protect data with a password, perform coding and medical records officers uphold honesty as well as the enforcement of the law or the laws of this study adallah tertentu. Simpulan in Genetic screening as a way to facilitate the early detection of a disease will be. In its implementation, data confidentiality must be guaranteed by a medical practitioner recorder by applying some way and uphold professional ethics.
\end{abstract}

Keywords: Genetic screening, DNA, medical records, confidentiality.

\begin{abstract}
Abstrak
Tujuan penelitian ini adalah untuk mengetahui peran rekam medis dalam penerapan metode genetic screening. Jenis penelitian ini adalah deskriptif kualitatif dengan pendekatan studi dokumen. Dokumen berupa beberapa jurnal internasional yang memuat kasus genetic screening serta buku lain yang relevan.Genetic Screening atau pada umumnya disebut tes DNA adalah suatu metode untuk mengetahui kelainan yang terjadi di dalam DNA. Hasil genetic screening dapat di gunakan sebagai acuan langkah preventif suatu penyakit. Namun dampak buruk dari genetic screening adalah adanya diskriminasi yang merugikan tidak hanya bagi individu tersebut namun juga lingkungan sekitarnya. Diskriminasi ini dapat diminimalisir dengan pelaksanaan manajemen rekam medis yang baik dan benar meliputi pengisian informed consent, pembuatan database ganda, memproteksi data dengan password, melakukan coding dan petugas rekam medis menjunjung tinggi kejujuran serta pemberlakuan hukum atau perundang undangan tertentu.Simpulan dalam penelitian ini adallah Genetic Screening sebagai salah satu cara untuk mempermudah deteksi dini akan suatu penyakit. Dalam pelaksanaanya, kerahasiaan data harus dijamin oleh praktisi perekam medis dengan menerapkan beberapa cara serta menjunjung tinggi etika profesi.
\end{abstract}

Kata Kunci: Genetic screening, DNA, rekam medis, kerahasiaan.

\section{PENDAHULUAN}

Menurut Burke (2011) Genetic Screening atau tes DNA secara konvensional di deskripsikan sebagai evaluasi sebagian populasi manusia untuk mendeteksi penyakit atau kelainan yang ada dalam tubuh dengan tujuan meningkatkan derajat kesehatan. Tes DNA juga di gunakan untuk mendeteksi agen pembawa pada beberapa penyakit turunan. Tes DNA ini dapat di terapkan pada beberapa kategori, diantaranya untuk bayi baru lahir, sistem reproduksi dan identifikasi penyakit turunan. Tes ini secara umum dianjurkan di Amerika terutama berkaitan dengan peninjauan sejarah penyakit pada suatu keluarga. Salah satu organisasi yang mendukung tes DNA diterapkan adalah American Centers for Disease Control and Prevention. Mereka menganjurkan pada 
setiap individu untuk mengenal dan mengetahui sejarah status kesehatan keluarganya kemudian berkonsultasi dengan penyedia pelayanan kesehatan setempat sebagai langkah preventif.

\section{METODE PENELITIAN}

Penelitian ini menggunakan penelitian deskriptifkualitatif dengan pendekatan study document. Penelitian dilaksanakan dengan menggunakan beberapa jurnal internasional diantaranya Oxford Journals dan Jurnal Departemen Kesehatan California, Amerika Serikat. Teknik pengumpulan data menggunakan study document, dimana penelitian ini membandingkan beberapa jurnal yang dijadikan referensi penulisan.

Keterbatasan penelitian ini tidak dapat memanfaatkan teknik pengambilan data observasi kegiatan genetic screening secara langsung. Hal ini dikarenakan metode genetic screening belum sepenuhnya di legalisasi di Indonesia.

\section{HASIL DAN PEMBAHASAN}

\section{1) Prosedur Genetical Screening}

Genetical Screening merupakan salah satu bagian dari konsultasi genetik. Menurut Allingham-Hawkins (2008) jika seseorang ingin melakukan tes tersebut atau tes lain yang memiliki ruang lingkup yang sama mengenai gen seperti konsul genetik, perawatan dokter dan lain lain maka terlebih dahulu harus mengisi inform consent sebelum melakukan tes. Tes genetik ini menggunakan sample darah, rambut, kulit, cairan amniotik (cairan ketuban pada masa kehamilan) ataupun sample jaringan lain. Contohnya, sebuah prosedur medis yang disebut buccal smear menggunakan sikat kecil atau kain kapas untuk mengumpulkan sample sel dari permukaan dalam pada pipi. Secara alternatif, sejumlah ludah akan terambil bersama dengan sejumlah sel yang terkandung pada ludah tersebut. Sample tersebut akan dibawa ke laboratorium dimana petugas laboratorium akan mengidentifikasi sifat DNA, protein atau hal lain yang berkaitan. Beberapa minggu kemudian, hasil dari tes akan keluar dan individu akan mengetahui penyakit apa saja yang memiliki kemungkinan terjadi pada tubuhnya.
Selain itu juga dapat diketahui apakah ada abnormal/anomali gen pada tubuhnya. Individu tersebut akan mengetahui bagaimana sifat gen dalam tubuhnya dan jika dia mempergunakan hasil tes tersebut dengan baik maka individu tersebut akan berusaha memperbaiki tingkat kesehatannya.

\section{2) Dampak Positif dan Negatif Genetic Screening}

Dalam pelaksanaannya, Menurut Billings (1992) genetic screening telah memunculkan berbagai dampak positif dan negatif. Dampak positif dari pelaksanaan tes ini diantaranya, seseorang yang telah mengetahui penyakit apa yang mungkin muncul dalam dirinya akan melakukan langkah preventif dimana tujuannya adalah untuk meminimalisir presentase penyakit tersebut untuk muncul.

Hal ini secara langsung akan meningkatkan derajat kesehatan seseorang. Upaya upaya preventif tersebut diantaranya adalah individu mulai mengubah gaya hidupnya mulai dari pola makan, jam istirahat, beberapa makanan pantangan yang memungkinkan menimbulkan resiko, rutin berolahraga, menjauhi minuman keras dan atau merokok serta menjaga kebersihan dan lingkungan dirinya. Bagi individu yang sudah ter-suspend, hasil dari genetic screening ini dapat dijadikan sebagai acuan dalam pemberian terapi, pemberian supply nutrisi berupa makanan atau obat obatan, serta menjauhi pantangan sesuai dengan kondisi pasien yang sudah dijabarkan melalui genetic screening. Hal ini tentunya sangat membantu akan kesembuhan pasien yang ter-suspend.

Meskipun genetic screening memegang kendali yang cukup penting sebagai acuan pemberian tindakan medis pada pasien yang telah tersuspend ataupun yang memiliki resiko suspend, menurut Billings (1992) genetic screening juga memiliki beberapa sisi negatif. Sisi negatif tersebut antara lain adalah ketakutan seorang individu akan sesuatu hal yang belum terjadi serta terjadinya berbagai diskriminasi terlebih apabila akses data dapat dilakukan kapan saja oleh siapa saja. Misalnya, setelah genetic screening dilaksanakan dan hasilnya sudah keluar maka diketahui bahwa seorang individu diperkirakan mengidap kanker payudara. Meski itu hanya perkiraan namun individu tersebut 
akan merasa cemas dan kalut akan hasil tes. Hal ini akan berdampak pada psikologis individu yang mungkin akan mengganggu aktivitas sehari harinya.

Di negara negara maju, diskriminasi dapat terjadi dengan tingkat kefatalan tinggi. Diskriminasi adalah tindakan yang memperlakukan satu orang atau satu kelompok secara kurang adil atau kurang baik daripada orang atau kelompok yang lain. Diskiminasi dapat dilakukan oleh individu, kelompok atau kebijakan dan praktik organisasi.Beberapa kasus diskriminasi serta dampak negatif ada pada tabel berikut:

Tabel 1. Studi Dokumentasi Terhadap Jurnal Tentang Genetic Screening

\begin{tabular}{|c|c|c|c|}
\hline No. & $\begin{array}{c}\text { Judul } \\
\text { Jurnal }\end{array}$ & Tahun & Kasus Diskriminasi \\
\hline 1 & $\begin{array}{l}\text { Discrimination } \\
\text { as A } \\
\text { Consequence } \\
\text { of Genetic } \\
\text { Testing }\end{array}$ & 1992 & $\begin{array}{l}\text { Seorang wanita ditolak } \\
\text { oleh sebuah rumah sakit } \\
\text { dikarenakan sepupunya } \\
\text { telah di diagnosis } \\
\text { memiliki cystic fibrosis. } \\
\text { Wanita tersebut meminta } \\
\text { untuk dilakukan tes } \\
\text { berkelanjutan atas } \\
\text { penolakan rumah sakit } \\
\text { tentang apakah dia juga } \\
\text { memiliki kemungkinan } \\
\text { mengidap cystic fibrosis } \\
\text { atau tidak. Setelah } \\
\text { melakukan tes tersebut, } \\
\text { wanita ini diketahui } \\
\text { memiliki carrier CF } \\
\text { dan dalam hasil tes } \\
\text { diterangkan bahwa dia } \\
\text { ataupun anak yang akan } \\
\text { dia miliki kelak tidak akan } \\
\text { dapat terhindar dari carrier } \\
\text { CF ini meskipun suaminya } \\
\text { sama sekali tidak memiliki } \\
\text { carrier CF. Setelah itu, } \\
\text { wanita tersebut tidak lagi } \\
\text { memperoleh tunjangan } \\
\text { asuransi lagi. }\end{array}$ \\
\hline 2 & $\begin{array}{l}\text { Task Force } \\
\text { On Genetic } \\
\text { Information } \\
\text { and Insurance }\end{array}$ & 1992 & $\begin{array}{l}\text { Lembaga penjamin } \\
\text { asuransi memperdebatkan } \\
\text { validasi seorang lelaki } \\
\text { untuk mendaftarkan } \\
\text { asuransi setelah hasil tes } \\
\text { keluar meskipun penyakit } \\
\text { Huntington Dis ease } \\
\text { yang diperkirakan belum } \\
\text { menunjukkan tanda } \\
\text { tanda ataupun symptom. } \\
\text { Setelah diadakan tes } \\
\text { ulang, lembaga asuransi } \\
\text { ini akhirnya mengizinkan. } \\
\text { Namun perawatan medis } \\
\text { yang diperoleh oleh lelaki } \\
\text { ini tidak sesuai dengan } \\
\text { apa yang sebenarnya dia } \\
\text { butuhkan. Selain ituketika }\end{array}$ \\
\hline
\end{tabular}

\begin{tabular}{|c|c|c|c|}
\hline No. & $\begin{array}{c}\text { Judul } \\
\text { Jurnal }\end{array}$ & Tahun & Kasus Diskriminasi \\
\hline & & & $\begin{array}{l}\text { istrinya akan mendaftarkan } \\
\text { asuransi, prosedur yang } \\
\text { dilakukan oleh istri } \\
\text { penderita Huntington } \\
\text { Disease tersebut sedikit } \\
\text { rumit. Lembaga asuransi } \\
\text { tersebut mengajukan tiga } \\
\text { persyaratan, salah satu } \\
\text { dari persyaratan tersebut } \\
\text { adalah menyangkut resiko } \\
\text { keluarganya tentang } \\
\text { penyakit kanker kolon, } \\
\text { meskipun dalam tes tidak } \\
\text { menunjukkan adanya } \\
\text { tanda tanda kanker kolon. }\end{array}$ \\
\hline 3 & $\begin{array}{l}\text { The Human } \\
\text { Genome } \\
\text { Initiative: } \\
\text { Genetic's } \\
\text { Lightning Rod }\end{array}$ & 1991 & $\begin{array}{l}\text { Pada tahun } 1979 \text { seorang } \\
\text { perempuan ditolak ditolak } \\
\text { oleh sebuah perusahaan } \\
\text { untuk bekerja karena } \\
\text { memiliki indikasi penyakit } \\
\text { CMT. Padahal sebelumnya } \\
\text { pekerja a t e r e bu t } \\
\text { ditawarkan oleh perusahan } \\
\text { itu sendiri kepada wanita } \\
\text { tersebut. }\end{array}$ \\
\hline
\end{tabular}

Diskriminasi yang dapat terjadi atas hasil tes adalah jika ditemukan anomali atau ketidaknormalan gen yang menyebabkan seseorang memiliki penyakit genetik, maka penderita tersebut akan sulit untuk mendapatkan pekerjaan karena hasil tes dapat diakses oleh siapapun. Selain itu, jika individu tersebut mengajukan asuransi, dan pihak asuransi dapat mengakses informasi mengenai hasil tes individu tersebut, maka besar kemungkinan pihak asuransi tersebut akan menaikkan biaya asuransi mengingat adanya anomali pada gen, atau bahkan perusahaan asuransi tersebut akan sepenuhnya menolak individu tersebut untuk melakukan admisi asuransi.

Diskriminasi merupakan konsekuensi bagi individu yang melakukan tes tersebut. Diperlukan studi tertentu akan penanganan diskriminasi mengingat dampak dari diskriminasi tidak hanya pada mental penderita saja, namun juga akan berdampak pada kehidupan atau aktivitas sosialnya bahkan keluarga penderita dapat juga menjadi sasaran diskriminasi karena relasi darahnya yang dekat sehingga orang akan berfikir bahwa keluarga individu tersebut juga memiliki gen yang hampir sama.

\section{3) Peranan Perekam Medis dalam Kasus Dis- kriminasi Hasil Genetic Screening}


Menurut Permenkes 269 tahun 2008, rekam medis adalah berkas yang berisikan catatan dan dokumen tentang : 1). identitas pasien 2). pemeriksaan 3). pengobatan 4). tindakan 5). pelayanan lain yang telah diberikan kepada pasien. Seperti yang kita ketahui bahwa seorang perekam medis memiliki tanggung jawab atas pengelolaan data pasien, seperti yang tercantum pada Permenkes 55 Tahun 2013 pasal 18 tentang Kewajiban Perekam Medis, antara lain adalah : a). menghormati hak pasien/klien b). Menyimpan rahasia pasien sesuai dengan peraturan perundang undangan c). memberikan data dan informasi kesehatan berdasarkan kebutuhan sesuai dengan ketentuan peraturan perundang undangan d). membantu program pemerintah dalam rangka meningkatkan derajat kesehatan masyarakat, dan 5). mematuhi standar profesi, standar pelayanan dan standar prosedur operasional.

Dalam pelaksanaan kerjanya, menurut Budi (2011) bahwa pada Kepmenkes 377 Tahun 2007 seorang perekam medis harus memenuhi aspek rekam medis yaitu ALFRED. ALFRED merupakan singkatan dari Administration, Legal, Financial, Research, Education dan Documentation.

Dalam pelaksanaan genetic screening maka aspek yang dipegang oleh seorang perekam medis adalah aspek legal dan aspek dokumentasi. Aspek legal yaitu sebagai aspek hukum atas bukti pelayanan pasien. Hal ini menerangkan bahwa rekam medis dapat digunakan sewaktu waktu jika terjadi penyalahgunaan informasi atas riwayat penyakit seseorang karena pada dasarnya sifat berkas rekam medis adalah rahasia. Sifat kerahasiaan berkas rekam medis ini merupakan dasar pada aspek documentation. Seorang perekam medis harus benar benar menjaga kerahasiaan atas informasi ataupun riwayat penyakit seseorang.

Selain memegang aspek legal dan documentation pada kasus diskriminasi hasil genetic screening, seorang perekam medis juga berkewajiban untuk menerapkan kompetensi dasar rekam medis. Tepatnya adalah kompetensi kedua perekam medis, yaitu terkait dengan aspek hukum dan etika profesi. Pada kompetensi ini seorang perekam harus mampu memfasilitasi pelepasan informasi kesehatan kepada pasien maupun pihak ketiga, menyiapkan informasi pasien kepada pihak yang berhak, menjaga keamanan alur permintaan informasi kesehatan, memelihara kerahasiaan informasi pasien, mengidentifikasi resiko tinggi dalam kerahasiaan informasi kesehatan, mengevaluasi faktor resiko dalam pendokumentasian dan kerahasiaan informasi kesehatan, melaksanakan kebijakan dan prosedur akses dan pelepasan informasi, melaksanakan kebijakan dan prosedur terkait dengan peraturan pendokumentasian, mengkoordinasikan kegiatan komite keamanan informasi kesehatan, serta membuat pedoman training, peraturan dan prosedur yang terkait dengan informasi pelayanan pasien. Dari sepuluh poin diatas, poin yang paling penting adalah tentang memelihara kerahasiaan informasi pasien atas kasus diskriminasi genetic screening.

Jika genetic screening secara terbuka sudah dilegalkan di Indonesia, maka dalam upaya pencegahan kebocoran informasi kesehatan, kompetensi perekam medis diatas belumlah cukup karena belum di dukung oleh sarana prasarana yang dapat membantu terjaminnya kerahasiaan informasi kesehatan. Berikut adalah beberapa solusi dalam penanganan penyalahgunaan informasi kesehatan yang berujung diskriminasi:

a. Sistem Database

Setiap rumah sakit tentulah memiliki sistem informasi yang menjadi kunci utama dalam pengolahan data pasien. Data pasien yang terkelompok menjadi satu disebut database. Pada sistem informasi kesehatan di instansi pelayanan kesehatan khususnya pelayanan kesehatan yang sudah menyediakan genetic screening, database yang berisikan data serta hasil tes haruslah diolah hanya oleh perekam medis. Hal ini di maksudkan untuk menjaga kerahasiaan data. Databasetersebut diusahakan dibuat ganda untuk back-up data sehingga jika suatu saat data tersebut hilang, maka backup data masih tersedia.

b. Proteksi Sandi

Untuk menghindari penyalahgunaan data, maka database tersebut haruslah diberikan proteksi sandi atau password, sehingga akan menyulitkan hacker jika ingin menyalahgunakan data atau menyadap data. Sandi atau password tersebut haruslah diubah secara berkala untuk menghindari kebocoran sandi. 
c. Coding

Selanjutnya, dibuatlah databasecoding bagi hasil tes genetic screening. Hasil tes akan di konversikan kedalam kode yang tidak mudah dipahami oleh orang awam. Hal ini akan menyulitkan bagi hacker jika mereka berhasil membobol password, karena tidak semua orang mengerti coding. Petugas rekam medis harus teliti dan cermat dalam melakukan coding agar tidak terjadi kesalahan.

d. Pengisian Informed Consent

Regulasi diluar database adalah pengisian informed consent bagi siapapun yang akan mengajukan permintaan informasi kesehatan dan harus disetujui oleh individu pemilik data. Hal ini dilakukan untuk melindungi data tersebar dengan luas dengan kasus level kepentingan yang rendah dimana dapat terjadi kemungkinan penyalahgunaan informasi. Dengan persetujuan pemilik data atau pasien maka data dapat dipergunakan seperlunya dan tidak sia sia.

e. Etika Profesi Rekam Medis

Selain informed consentyang bersifat teknis dan dokumentatif, peran rekam medis atas tanggung jawabnya dalam etika profesi juga menjadi hal yang penting. Suatu sistem takkan berjalan dengan baik jika pelaku dari pekerjaan itu tidak memiliki tanggung jawab dan etika. Selain itu, perekam medis juga harus mampu menjunjung tinggi etika kerja serta kejujuran dan kerahasiaan. Banyaknya resiko atau dampak negatif dari pelaksanaan genetic screening dapat di minimalisir dengan pengelolaan manajemen informasi kesehatan yang baik, rahasia dan jujur.

f. Sistem Legalitas atau Hukum

Hukum sebagai dasar ditentukannya penyelesaian permasalahan merupakan aspek penting dalam penanganan kasus ini. Tanpa hukum maka tidak ada dasar untuk penyelesaian dan pertimbangan masalah. Pemerintah bekerja sama dengan Departemen Kesehatan harus menentukan hukuman apa yang akan diberikan pada pelanggar. Selain untuk menegakkan keadilan, hal ini akan membuat jera pada pelanggar yang menyalahgunakan informasi kesehatan.

\section{SIMPULAN}

Genetic Screening atau pada umumnya disebut tes DNA adalah suatu metode untuk mengetahui kelainan yang terjadi di dalam DNA. Tes ini akan mengidentifikasi sifat DNA dalam tubuh kita. Hasil genetic screening dapat di gunakan sebagai acuan langkah preventif suatu penyakit. Namun dampak buruk dari genetic screening adalah adanya diskriminasi yang merugikan tidak hanya bagi individu tersebut namun juga lingkungan sekitarnya. Diskriminasi ini dapat diminimalisir dengan pelaksanaan manajemen rekam medis yang baik dan benar meliputi:

1. pengisian informed consent

2. pembuatan database ganda

3. memproteksi data dengan password

4. melakukan coding

5. petugas rekam medis menjunjung tinggi kejujuran serta etika profesi.

6. pemberlakuan hukum atau legalitas tertentu

\section{DAFTAR PUSTAKA}

Allingham-Hawkins, Diane. 2008. "Successful Genetic Tests Are Predicated on Clinical Utility". Genetic Engineering \& Biotechnology News. New York :Mary Ann Liebert

Beckwith J .1991. The Human Genome Initiative: Genetic'sLightning Rod.AmJLaw Med40:1-13

Billings, Paul R. 1992. Discrimination as A Consequence of Genetic Testing. California: California Pacific Medical Center.

Budi, Savitri Citra. 2011. Manajemen Unit Kerja Rekam Medis. Yogyakarta : Quantum Sinergis Media

Burke, Wylie. 2011. Oxford Journals : Genetic Screening. Oxford : Oxford University

Department of Health and Human Services of America. 1993. Task Force On Genetic Information and Insurance : Genetic Information and Health Insurance. Maryland : United States of America

Menkes RI. 2013. Permenkes RI No. 55 Tahun 2013 tentang Penyelenggaraan Pekerjaan Perekam Medis. Jakarta : Indonesia 